\title{
Mycorrhizal Inoculation of Chestnut Seedlings: Effect on Survival and Growth after Transplantation
}

\author{
A. Martins ${ }^{\mathrm{a}}$ \\ Instituto Politécnico de Bragança \\ Escola Superior Agrária \\ Campus de Santa Apolónia - Apartado 1172 \\ 5301 - 854 Bragança \\ Portugal
}

\begin{abstract}
Trees of several species cannot develop without mycorrhizas. The first trials of controlled mycorrhization were made in Australia early in the twentieth century. Mycorrhizal inoculation is based on the main findings: (1) any mycorrhiza is better than none for plants produced in greenhouses/nurseries; (2) some species are more beneficial than others under specific environmental conditions.

Building on mycorrhizal studies on chestnut (Castanea sativa Mill.) inoculated plants, work was started on inoculum production in order to inoculate chestnut plants in greenhouse/nursery and evaluate its effects. A consortium programme was started with the production of inoculum and mycorrhization of seedlings in greenhouse, followed by transference to nurseries. We report the methodology and results obtained in three year long trials with chestnut tree seedlings mycorrhization with Pisolithus tinctorius. Mycorrhizal effects were analyzed through germination rates, survival and growth along the germination, and weaning processes.

Inoculation of the germination substrate did not influence germination rates, but affected plant growth: mycorrhizal plants are thicker than non-mycorrhizal ones. Inoculation of the substrate at sowing followed by previous acclimation revealed more favourable for plant survival and growth than inoculation and direct transfer to the nursery. When in contact with soils infected by Phytophthora cinnamomi mycorrhizal plants revealed higher survival capacity than nonmycorrhizal plants although this survival is dependent on the time of mycorrhization.
\end{abstract}

\section{INTRODUCTION}

The first trials of controlled mycorrhization in forestry happened in greenhouses in Australia, in the second decade of the $20^{\text {th }}$ century. Pinus radiata seedlings were inoculated with Rhizopogon luteolus carpophores. The first tests for production of inoculum in pure culture in solid substrate with nutrient medium were made in Hungary (Bokori, 1954). The method was used in small scale in the US, since 1970 and in large scale from 1982 (Marx et al., 1982, 1984). In France, the first mycorrhization tests in greenhouses occurred in 1979, using seedlings of the genus Picea and Pseudotsuga (Le Tacon and Valdenaire, 1980).

The belief was that improving plant growth by controlled mycorrhization only had interest in areas devoid of natural inoculum. However, in all natural forest soils and in many soils of greenhouses and nurseries, plant growth is not possible without a functional mycorrhizal complex. Resumption of growth and behaviour of plants introduced in the forest depends on the mycorrhizal symbionts that associate with them. At the time of transplantation, associated fungi come mainly from greenhouse or nursery soils. It is thus necessary that a good mycorrhizal system installs during the nursery production, and that this system is not destroyed at the time of seedlings transplantation (Le Tacon et al., 1997).

In forest plantations the increase in biomass resulting from growth enhancement by mycorrhizas is particularly important. Some fungi are more effective than others in

\footnotetext{
aamartins@ipb.pt
} 
promoting the growth of the host. To maximize the beneficial effects of the fungus, the plants should be inoculated with those selected, during seeds germination (Kuek, 1994).

Inoculation of plants in greenhouses and nurseries requires the production of mycorrhizal inoculum in large quantities and low prices (Kuek, 1994; Le Tacon, 1997). The first techniques of mycorrhizal inoculation used soils with high mycorrhizal potential removed from stands of related species, or plants or roots of plants previously inoculated.

Many species of mycorrhizal fungi can be inoculated with mycelium produced in pure culture, while many others have very low growth rates or simply do not grow.

The mycorrhization of Castanea sativa plants was previously induced in seedlings and micropropagated plants (Martins, 1992; Martins et al., 1996, 1997). Following the studies on mycorrhization of chestnut plants, the production of mycorrhizal inoculum for inoculation in greenhouse and nursery was started aiming at evaluating the effect of mycorrhization in the field. Transfer of the technology from laboratory scale to manufacturers, forestry and agro-forestry companies and enterprises was also in mind.

\section{MATERIALS AND METHODS}

\section{Seeds Germination}

Seeds were disinfected and pre-germinated in sand. Inoculation was performed at sown and acclimatization induced 3 months after inoculation under different conditions. Trial 1: Plants were transferred to soil in the greenhouse and transplanted with bare roots to the field in the next spring; Trial 2: Plants were directly transferred from trays to field conditions; Trial 3: Plants were transferred to pots and pre-acclimatized in the greenhouse. Transplantation to the field was made in the next spring with the pot soil.

\section{Inocula Production and Inoculation}

Mycorrhizal inocula were produced in vermiculite-peat moss (3:1) substrate. Pisolithus tinctorius grown in liquid modified Melin and Norkrans, MMN, medium (without casaminoacids and malt extract and with $5 \mathrm{~g} / \mathrm{L}$ glucose) for 4 weeks was added to the substrate previously prepared and incubated at $22^{\circ} \mathrm{C}$ for six weeks. This inoculum was applied along rows, under the seedlings at sown, in trays. Each bench had 64 trays with 30 seeds per tray, 32 trays per bench of which were inoculated.

\section{Mycorrhization Assessment}

Assessment of the state of mycorrhization was made by random sampling of 1 plant per tray on alternate trays (totalling 32 plants per bench) and 60 plants per time of assessment, during the pre-acclimation and acclimation.

The root systems were observed under naked eye and the stereomicroscope. Evaluation of the mycorrhization rate was made by estimation and expressed by the approximate estimated percentage of lateral mycorrhizal roots in the total mycorrhizal root system. The classes of percentage used in the estimation were: $[0,10],[10,25]$, $[25,50],[50,75]$ and $[75,100]$. The plants were grouped according to these classes and the percentage of plants in each class determined.

Plant roots were photographed under the microscope. Histological sections were cut to assess mycorrhizal characteristic structures; the mantle and Hartig net.

\section{Detection of Phytophthora}

Screening of ink disease by detection and isolation of its causative agent was carried out during the three year long trials. Ten plants per location were collected, and the fungus isolated in the collar and root tissues after disinfection with $3 \% \mathrm{NaClO}$. Samples of plant tissue were placed in selective medium P10VPH of Tsao and Guy (1997) and the mycelium growing in Petri dishes observed under the microscope to identify Phytophthora mycelium and structures after incubation for $24-48 \mathrm{~h}$ at $22-24^{\circ} \mathrm{C}$. 


\section{Survival}

Concerning the first year of testing, the survival rate was calculated at the end of the pre-acclimation in the greenhouse ( 180 days after sown/130 days after transplantation) and 1,2, 3 and 4 years after installation in the nursery.

Concerning the second year, considering that the plants were transferred directly to the nursery 50 days after sowing, the survival rates were calculated 60 days and 180 days after the transfer to the nursery and 1,2 and 3 years later.

Finally, in the third year of testing, the survival rates were calculated at the end of the pre-acclimation in greenhouse and in the shelter, 180 days after sowing and 130 days after bagging and 1 and 2 years after transfer to nursery.

\section{Evaluation of Growth Parameters}

For the first trial, at the end of the pre-acclimation, the height and diameter at the stem collar of 1312 plants per treatment were measured; in 144 trays; and 50 more plants per treatment in the field through three years.

For the second trial, 10 plants were randomly chosen by tray during germination, and they were measured in height and diameter at the neck. In each bench, 640 plants were measured, with a total of 1600 mycorrhizal plants (M) and 1600 non-mycorrhizal plants (NM). During acclimation, 10 plants per row and treatment after 60 and 120 days of acclimation were assessed, i.e., 160 plants per plot and treatment, with a total of 1280 plants. Surviving plants were also measured 1,2 and 3 years after transplantation.

For the third trial, 3 plants per tray were randomly chosen to measure height and diameter in a total of 96 plants per treatment and bench, 480 plants mycorrhizal plants (M) and 480 non-mycorrhizal plants (NM). During acclimation, plants were assessed after 60 and 120 days; i.e., 90 plants per plot and treatment. Surviving plants were also measured 1 and 2 years after transplantation.

\section{Mycorrhization and Monitoring of Growth Parameters}

The mycorrhizal process was monitored at various time periods in order to evaluate the mantle and Hartig net formation (macroscopically, stereomicroscopically and microscopically). Growth rates of mycorrhizal and nonmycorrhizal plants: heights (h), stem diameter at the collar level (dcollar), growth rates per time $(\Delta \mathrm{x} / \Delta \mathrm{t})$ and relative growth rates (RGR) were also determined.

Data were analyzed by one-way variance analysis, ANOVA, and significance of the calculated $\mathrm{F}$ values was established for probabilities lower than $5 \%, 1 \%$ and $0.1 \%$. For all results presented in the tables, the values of standard deviation (s) are indicated, and the values of different treatments followed by different letters correspond to parameters with statistically significant differences for $\mathrm{p}<0.05$.

\section{RESULTS}

\section{Germination Rates}

Germination rates at 5 to 30 days after sowing did not differ between inoculated and non-inoculated substrates: the majority of seeds germinate in the first 10 days.

\section{Survival Rates}

Survival was assessed during the initial period of pre-acclimation or/and after installation in the nursery under natural conditions, for each trial.

1. Trial 1. In these plants, transferred to soil in the greenhouse and transplanted with bare roots to the field in the next spring, there were no differences in survival rates between $M$ and NM plants during the time of pre-acclimation in greenhouse, while in the nursery we found significant differences one year after transplantation, when the survival of $M$ plants was higher and stayed so 3 years later (Table 1).

These results also show the influence of biotic factors on mortality that were not anticipated. Indeed, after transplantation to the nursery, some plants showed symptoms of 
Phytophthora cinnamomi infection. Mortality in M plants was a $15 \%$ lower when there was pathogen when it was compared with NM plants.

Isolation made from plants installed in the nursery showed that all the dead plants were infected with $P$. cinnamomi.

2. Trial 2. In the second year of trial there were significant differences in survival between $\mathrm{M}$ and NM plants, one month after the direct transfer to the nursery (carried out 50 days after sowing) (Table 2). After 180 days (120 days after transfer) decreased survival rates, with an overall survival of less than $30 \%$, with no statistical differences between treatments. Similar results were obtained the next year, and survival rate differences became significant again after one and two years being 33, 8\% higher than control. High mortality rates in all cases were found during the first six months of direct acclimation in the nursery (Table 2).

Plants transferred to the nursery 60 days after sowing showed high mortality rates in the first months of acclimation. The highest mortality rate was found in plants grown in non inoculated substrate (NM).

3. Trial 3. There were no differences in survival rates between $M$ and NM plants preacclimated in the greenhouse and under the shelter (180 days), and they were high in both cases (98.0-97.5\%). On the contrary, the survival of plants pre-acclimated in the shelter presented significant differences between $M$ and NM plants, being higher in $M$ plants (Table 3). One year after transplantation to the nursery, plants $M$ had survival rates $27 \%$ higher than NM, and 29\% higher after two years (Table 3 ).

Im terms of survival, trial 3 had the best survival rates $(71.9 \%$ of $\mathrm{M}$ plants and $55.6 \%$ of NM plants) while trial 2 showed the worst results ( $26 \%$ of plants and $19 \%$ of M vs. NM plants). Symptoms of disease caused by Phytophthora, confirmed by isolation of this pathogen from dead plants, was found to occur in all three years and nursery stands and it was not foreseen, revealing the contamination of the nursery soil with Phytophthora, although it did not have any crop (agricultural or forestry) for many years.

Survival rates of the three trials were quite different, the worst survival occurring in the second year, in which the plants were directly transferred to the nursery soil 50 days after sowing without pre-acclimation. One month after transplantation, survival rates of this test were similar to those obtained at the end of the other two tests. Three years after transplantation, only $19 \%$ of NM plants and $26 \%$ of M plants survived. Despite the transfer of plants to the nursery after a short stay in greenhouse seriously compromised the survival, the positive effect of inoculation could still be seen. Six months after transplantation half of the plants had died due to Phytophthora infection. From this date, the mortality rates were much lower, the higher mortality in the two years that followed, having been recorded for NM plants, thus accentuating the beneficial effect of inoculation.

\section{Assessment of the Mycorrhization State of the Plants}

1. Trial 1. Mycorrhizal structures were visible in most of the plants roots observed 50 days after sowing. Only $1.9 \%$ had mycorrhizas in extent $\geq 50 \%$ of the root, $78.8 \%$ of the plants have mycorrhizas in between 10 and $50 \%$ of the root, and $19.4 \%$ of the plants had less than $10 \%$ of secondary mycorrhizal roots (Table 4). From 50 to 180 days, there was a general increase in plant mycorrhization (Table 4).

2. Trial 2. In the second trial, 50 days after sowing, $96.9 \%$ of the plants had roots with mycorrhization rates below $50 \%$ and $20 \%$ of the plants had less than $10 \%$ of M roots. At 180 days in the nursery, $83.8 \%$ of $\mathrm{M}$ plants had between 10 and $50 \%$ of $\mathrm{M}$ roots, $13.8 \%$ had less than $10 \%$ of $M$ roots and $2.5 \%$ showed over $50 \%$ of $M$ roots (Table 5).

3. Trial 3. In the third trial all inoculated plants had mycelium of $P$. tinctorius growing around its roots. At 30 days of sowing, mycorrhizal structures were very scarce, $53.1 \%$ of plants observed had less than $10 \%$ of secondary $M$ roots, while $40.9 \%$ of the plants had between 10 and $25 \%$ of $\mathrm{M}$ roots, and only $5.9 \%$ of the plants had between 25 and $50 \%$ of $\mathrm{M}$ roots (Table 6). At 50 days, results were quite different, $67.8 \%$ of the plants had between 10 and $50 \%$ of $\mathrm{M}$ roots. Less than $50 \%$ of $\mathrm{M}$ roots occurred in only $7.2 \%$ of the plants observed (Table 6). 


\section{Growth Rates}

1. Trial 1. At the end of pre-acclimation in greenhouse (150 days), $M$ plants presented significant differences in height $(\mathrm{p}<0,05)$, but in diameter at the stem collar. One year after transfer to the nursery, the differences in height were still significant $(p<0,05)$. The increases in height $(\Delta \mathrm{h})$ and diameter at the neck $(\Delta \mathrm{D})$ during the 4 years of study differed significantly between M and NM plants, being higher in M plants (Tables 7 and 8). Same results were found for the monthly increase of these parameters $(\Delta \mathrm{h} / \Delta \mathrm{t}$ and $\Delta \mathrm{D} / \Delta \mathrm{t})$ and for relative growth rates (RGR).

2. Trial 2. Height and diameter at the stem collar level during the greenhouse phase (50 days) did not show significant differences between $\mathrm{M}$ and NM plants (average height $17.9 \mathrm{~cm}$ vs. $17.2 \mathrm{~cm}$, average diameter at the stem collar $0.39 \mathrm{~cm}$ vs. $0.40 \mathrm{~cm}$, in $\mathrm{M}$ and NM plants). Plants sown in the inoculated substrate (M) had significant differences in rates of growth in height and diameter at the collar level of the stem than non inoculated ones (NM), after a year of transfer to the nursery. The differences at two and three years were significantly higher reaching 19.0 and $28.5 \%$ for height and stem diameter respectively at three years of trial.

3. Trial 3. In trial 3, the growth in height and diameter at the collar level of the stem of $M$ and NM plants did not show significant differences at the end of germination (180 days) (Tables 11 and 12). M and NM plants in the pre-acclimation had different growth rates in the greenhouse and shelter. Both M and NM plants had lower rates of growth in height when pre-acclimated in the shelter than the pre-acclimated in the greenhouse. In all locations there were no differences in height between $\mathrm{M}$ and NM pre-acclimated plants.

Two years after transplantation to the nursery, $M$ plants heights showed no significant differences from NM plants, although $\mathrm{M}$ plants had heights significantly higher one year after transfer. However, the increases in height during that period $(\Delta \mathrm{h})$ and monthly $(\Delta \mathrm{h} / \Delta \mathrm{t})$ and RGR were higher in M plants. The diameter of the stem at the collar level, the increases in diameter, the monthly increases in diameter and RGR in diameter were significantly higher in M plants (Tables 11 and 12).

\section{DISCUSSION}

Our results agree with several authors concerning to: (1) the mycorrhizal fungi need time to associate with roots, allowing at least $50 \%$ of the root volume to be colonized at transplantation (Marx et al., 1984, 1991); (2) In soils contaminated with pathogens, increased resistance of mycorrhizal plants depends on the time between the formation of mycorrhizae and contact with the pathogen. The bigger this time increases the probability of survival of plants (Stenström et al., 1997; Singh et al., 2000). In our study, after transfer to the nursery, plants did not have a root system with an association with sufficient time and extension to ensure full benefit. However, the advantage of mycorrhization in C. sativa was a significantly higher survival of M plants, extending the findings of Le Tacon et al. (1997) to adverse conditions. The benefit is higher in plants where the establishment of the fungus in the roots is more effective (higher percentage of mycorrhization) and for a longer time, confirming this assumption. The plants of trials 1 and 3 , having been subjected to pre-acclimation, were able to create a more stable and extensive association with mycorrhizal fungi than those of trial 2, which were transplanted to non-sterile soil 50 days after sowing with much lower mycorrhization. This is confirmed by the values of the mycorrhization rates of plants in each of the tests.

Death of C. sativa was due to infection by Phytophthora, and the higher resistance of $C$. sativa plants could be due to the improved general physiological conditions, implying that in the absence of contaminated soil they survive better as it was pointed out by Buscot et al. (1992). The use of inoculation with P. tinctorius as a biological tool to increase the survival and growth of plants in poor soils and degraded sites had already been suggested by Marx et al. (1984, 1991). The results of survival of M plants in contaminated soils showed that mycorrhizas can effectively be used as a biological tool to overcome these problems of contamination. We provided evidence that the increase in survival justifies the economic interest of mycorrhizal inoculation of chestnut plants as in 
other crops (Kropp and Langlois, 1990; Kuek, 1994).

\section{Literature Cited}

Bokor, R. 1954. A mykorrhiza-gombàkkal tor téno talajoltàsok ùj agrotechnikai eljàràsa. Erdészeti Kutatàsok. Budapest. 11-27-54. In: Le Tacon et al., 1997.

Buscot, F., Weber, G. and Oberwinkler, F. 1992. Interactions between Cylindrocarpon destructans and ectomycorrhizas of Picea abies with Laccaria laccata and Paxillus involutus. Trees 6:83-90.

Kropp, B.R. and Langlois, C.-G. 1990. Ectomycorrhizae in reforestation. Can. J. For. Res. 20:438-451.

Kuek, C. 1994. Issues concerning the production and use of inocula of ectomycorrhizal fungi in increasing the economic productivity of plantations. p.221-230. In: A.D. Robson, L.K. Abbott and N. Malajczuk (eds.), Management of mycorrhizas in agriculture, horticulture and forestry.

Le Tacon, F., Mousain, D., Garbaye, Bouchard, D., Churin, J.-L., Argillier, C., Amirault, J.-M. and Généré, B. 1997. Mycorhizes, pépinières et plantations en France. Rev. For. Fr. No Sp. 131-154.

Le Tacon, F. and Valdenaire, J.-M. 1980. La mycorhization controlé en pépinière, premiers résultats obtenus a la pépinière du Fonds forestier national de Peyrat leChâteau sur Épicea et Douglas. Rev. For. Fr. XXXII. 3:281-292.

Martins, A. 1992. Micorrização in vitro de plantas micropropagadas de Castanea sativa Mill. Dissertação para obtenção do grau de mestre. Faculdade de Ciências de Lisboa.

Martins, A., Barroso, J. and Pais, M.S. 1996. Effect of ectomycorrhizal fungi on survival and growth of micropropagated plants and seedlings of Castanea sativa Mill. Mycorrhiza 6:265-270.

Martins, A., Casimiro, A. and Pais, M.S. 1997. Influence of mycorrhization on physiological parameters of Castanea sativa Mill micropropagated plants. Mycorrhiza 7:161-165.

Marx, D.H., Cordell, C.E., Kenney, D.S., Mexal, J.G., Artman, J.D., Riffle, J.W. and Molina, R.J. 1984. Commercial vegetative inoculum of Pisolithus tinctorius and inoculation techniques for development of ectomycorrhizae on bare-root tree seedlings. Suppl. Forest Science. Monograph 25. Vol. 30(3), 101p.

Marx, D.H., Ruehle, J.L. and Cordell, C.E. 1991. Methods for studying nursery and field response of trees to specific ectomycorrhiza. p.384-411. In: J.R. Norris, D.J. Read and A.K. Varma (eds.), Methods in Microbiology, Vol. 23.

Singh, R., Adholeya, A. and Mukerji, K.G. 2000. Mycorrhiza in control of soil born pathogens. p.173-196. In: K.G. Mukerji and J. Singh (eds.), Mycorrhizal Biology. Kluwer Academic/Plenum Publishers.

Stenström, E., Damm, E. and Unestam, T. 1997. Le rôle des mycorrhizes dans la protection des arbres forestiers contre les agents pathogènes du sol. Rev. For. Fr. $\mathrm{n}^{\mathrm{o}} \mathrm{sp}$. 121-128.

Tsao, P. and Guy, O. 1997. Inibition of Mortierella and Pythium in a Phytophthora isolation medium containig hymexazol. Phytopathology 50:717-801. 


\section{$\underline{\text { Tables }}$}

Table 1. Survival rates of inoculated (M) and non-inoculated (NM) plants of the first trial after the pre-acclimation in greenhouse and after the transfer to the nursery. Values of standard deviation (S) and the mean values of different treatments followed by different letters that correspond to parameters with statistically significant differences for $\mathrm{p}<0.05$ are represented.

\begin{tabular}{lllllll}
\hline \multirow{2}{*}{ First trial } & \multicolumn{2}{c}{$\begin{array}{c}\text { Pre- } \\
\text { acclimatization }\end{array}$} & \multicolumn{3}{c}{ Acclimatization - Nursery } \\
\cline { 3 - 6 } & & \multicolumn{1}{c}{180 days } & Year 1 & Year 2 & Year 3 & \multirow{2}{*}{ Year 4 } \\
\hline \multirow{2}{*}{$\mathrm{NM}$} & $\%$ & $84,2 \mathrm{a}$ & $61,1 \mathrm{a}$ & $53,5 \mathrm{a}$ & $49,6 \mathrm{a}$ & $47,1 \mathrm{a}$ \\
& $\mathrm{S}$ & 18,4 & 15,2 & 14,4 & 14,5 & 15,3 \\
\hline \multirow{2}{*}{$\mathrm{M}$} & $\%$ & $82,4 \mathrm{a}$ & $72,8 \mathrm{~b}$ & $69,3 \mathrm{~b}$ & $64,1 \mathrm{~b}$ & $61,7 \mathrm{~b}$ \\
& $\mathrm{~S}$ & 16,5 & 20,0 & 22,3 & 21,9 & 21,6 \\
\hline
\end{tabular}

Table 2. Survival rates of plants of the second trial after direct transfer to the nursery. Values of standard deviation (S) and the mean values of different treatments followed by different letters that correspond to parameters with statistically significant differences for $\mathrm{p}<0.05$ are represented.

\begin{tabular}{lllllll}
\hline \multirow{2}{*}{ Second trial } & & \multicolumn{5}{c}{ Acclimatization - Nursery } \\
\cline { 3 - 7 } & & \multicolumn{1}{c}{60 days } & 180 days & Year 1 & Year 2 & Year3 \\
\hline \multirow{2}{*}{ NM } & $\%$ & $58,7 \mathrm{a}$ & $26,3 \mathrm{a}$ & $22,8 \mathrm{a}$ & $19,9 \mathrm{a}$ & $19,2 \mathrm{a}$ \\
& $\mathrm{S}$ & 15,7 & 16,1 & 14,0 & 12,6 & 13,2 \\
\multirow{2}{*}{$\mathrm{M}$} & $\%$ & $66,5 \mathrm{~b}$ & $31,7 \mathrm{a}$ & $28,6 \mathrm{a}$ & $26,1 \mathrm{~b}$ & $25,7 \mathrm{~b}$ \\
& $\mathrm{~S}$ & 10,6 & 16,1 & 14,0 & 14,3 & 14,2 \\
\hline
\end{tabular}

Table 3. Survival rate of $\mathrm{M}$ and NM plants from the third trial during the pre-acclimation in greenhouses and shelter (180 days after sowing) and after acclimation in the nursery (1 and 2 years after transplantation). Values of standard deviation (S) and the mean values of different treatments followed by different letters that correspond to parameters with statistically significant differences for $\mathrm{p}<0.05$ are represented.

\begin{tabular}{lclccc}
\hline \multirow{2}{*}{ Third trial } & \multicolumn{2}{c}{ Pre-acclimatization } & \multicolumn{2}{c}{ Acclimatization } \\
\cline { 3 - 6 } & & \multicolumn{2}{c}{ Greenhouse } & Shelter & \multicolumn{2}{c}{ Nursery } \\
\cline { 3 - 6 } & & \multicolumn{2}{c}{ 180 days } & Year 1 & Year 2 \\
\hline \multirow{2}{*}{ NM } & $\%$ & $97,5 \mathrm{a}$ & $92,3 \mathrm{a}$ & $60,3 \mathrm{a}$ & $55,6 \mathrm{a}$ \\
& $\mathrm{S}$ & 0,91 & 8 & 11,6 & 12,1 \\
\hline \multirow{2}{*}{$\mathrm{M}$} & $\%$ & $98,0 \mathrm{a}$ & $96,0 \mathrm{~b}$ & $76,6 \mathrm{~b}$ & $71,9 \mathrm{~b}$ \\
& $\mathrm{~S}$ & 1,28 & 5,6 & 6,3 & 8,4 \\
\hline
\end{tabular}


Table 4. Mycorrhization rate of M plants 50 days after sowing and at 180 days after sowing during pre-acclimation in the greenhouse.

\begin{tabular}{lrrccc}
\hline$\%$ M Roots & ] $0,10[$ & {$[10,25[$} & {$[25,50[$} & {$[50,75[$} & {$[75,100]$} \\
\hline Days & \multicolumn{5}{c}{$\%$ plants with M roots } \\
\hline 50 & 19,4 & 45,0 & 33,8 & 1,9 & 0,0 \\
180 & 8,8 & 36,3 & 47,5 & 7,5 & 0,0 \\
\hline
\end{tabular}

Table 5. Mycorrhization rate of $\mathrm{M}$ plants at the end of germination in greenhouse (50 days) and during the acclimation period at 180 days in the nursery.

\begin{tabular}{lccccc}
\hline$\%$ M Roots & ] $0,10[$ & {$[10,25[$} & {$[25,50[$} & {$[50,75[$} & {$[75,100]$} \\
\hline Days & \multicolumn{5}{c}{$\%$ plants with M roots } \\
\hline 50 & 20,0 & 36,3 & 40,6 & 3,1 & 0,0 \\
180 & 13,8 & 42,5 & 41,3 & 2,5 & 0,0 \\
\hline
\end{tabular}

Table 6. Mycorrhization rate of $\mathrm{M}$ plants in the period of germination in greenhouse (at

30 and 50 days) and the pre-acclimation 180 days after bagging in the greenhouse.

\begin{tabular}{lcrrrr}
\hline$\%$ M Roots & ] $0,10[$ & {$[10,25[$} & {$[25,50[$} & {$[50,75[$} & {$[75,100]$} \\
\hline Days & \multicolumn{5}{c}{ \% plants with M roots } \\
\hline 30 & 53,1 & 40,9 & 5,9 & 0 & 0 \\
50 & 15,6 & 27,5 & 40,3 & 7,2 & 0 \\
180 & 5,2 & 25,3 & 54,9 & 14,6 & 0 \\
\hline
\end{tabular}

Table 7. Average height of inoculated (M) and non-inoculated plants (NM) 150 days after acclimation in greenhouse 1, 2 and 3 years after transfer to the nursery. They are also the increases in height during that period $(\Delta \mathrm{h})$, the monthly increases in height $(\Delta \mathrm{h} / \Delta \mathrm{t})$ and relative growth rate (RGR). Values of standard deviation (s) and the mean values of different treatments followed by different letters that correspond to parameters with statistically significant differences for $\mathrm{p}<0.05$ are represented.

\begin{tabular}{|c|c|c|c|c|c|c|c|c|c|}
\hline \multirow[b]{2}{*}{ h } & & \multicolumn{5}{|c|}{ Height $(\mathrm{cm})$} & \multirow{2}{*}{$\begin{array}{l}\Delta \mathrm{h} \\
(\mathrm{cm})\end{array}$} & \multirow{2}{*}{$\begin{array}{c}\Delta \mathrm{h} / \Delta \mathrm{t} \\
(\mathrm{cm} / \mathrm{month})\end{array}$} & \multirow{2}{*}{$\begin{array}{c}\text { TCR } \\
\text { (mm/cm/month) }\end{array}$} \\
\hline & & $\begin{array}{r}150 \\
\text { days }\end{array}$ & $\begin{array}{c}\text { Year } \\
1\end{array}$ & $\begin{array}{c}\text { Year } \\
2 \\
\end{array}$ & $\begin{array}{c}\text { Year } \\
3 \\
\end{array}$ & $\begin{array}{c}\text { Year } \\
4 \\
\end{array}$ & & & \\
\hline \multirow{2}{*}{ NM } & $\mathrm{h}$ & $51,7 \mathrm{a}$ & $78,7 \mathrm{a}$ & $117,7 \mathrm{a}$ & $155,4 a$ & $175,2 \mathrm{a}$ & $123,6 a$ & $2,58 \mathrm{a}$ & $0,146 \mathrm{a}$ \\
\hline & $\mathrm{S}$ & 7,12 & 21,6 & 26,2 & 28,9 & 36,1 & 36,3 & 0,76 & 0,001 \\
\hline \multirow{2}{*}{ M } & $\mathrm{H}$ & $53,5 b$ & $87,8 b$ & $128,4 \mathrm{~b}$ & $171,4 b$ & $191,9 b$ & $138,4 b$ & $2,94 b$ & $0,153 b$ \\
\hline & $\mathrm{S}$ & 8,21 & 22,1 & 25,3 & 34,3 & 39,8 & 43,1 & 0,90 & 0,002 \\
\hline
\end{tabular}


Table 8. Diameter of the stem at the collar level of inoculated plants (M) and noninoculated (NM) plants 150 days after acclimation in greenhouse, 1, 2 and 3 years after transfer to the nursery. The increases in diameter during this period $(\Delta \mathrm{D})$, the monthly increases in diameter $(\Delta \mathrm{D} / \mathrm{dt})$ and relative growth rate (RGR) are also shown. Values of standard deviation $(S)$ and the mean values of different treatments followed by different letters that correspond to parameters with statistically significant differences for $\mathrm{p}<0.05$ are represented.

\begin{tabular}{|c|c|c|c|c|c|c|c|c|c|}
\hline \multirow[b]{2}{*}{$\mathrm{D}_{\text {colla }}$} & & \multicolumn{5}{|c|}{ Stem diameter at the collar level $(\mathrm{cm})$} & \multirow{2}{*}{$\begin{array}{l}\Delta \mathrm{D} \\
(\mathrm{cm})\end{array}$} & \multirow{2}{*}{$\begin{array}{c}\Delta \mathrm{D} / \Delta \mathrm{t} \\
(\mathrm{cm} / \mathrm{month})\end{array}$} & \multirow{2}{*}{$\begin{array}{c}\text { TCR } \\
(\mathrm{mm} / \mathrm{cm} / \mathrm{month})\end{array}$} \\
\hline & & $\begin{array}{l}150 \\
\text { days }\end{array}$ & $\begin{array}{c}\text { Year } \\
1\end{array}$ & $\begin{array}{c}\text { Year } \\
2\end{array}$ & $\begin{array}{c}\text { Year } \\
3\end{array}$ & $\begin{array}{c}\text { Year } \\
4\end{array}$ & & & \\
\hline \multirow{2}{*}{ NM } & $\mathrm{D}_{\text {collar }}$ & $0,79 \mathrm{a}$ & $1,31 \mathrm{a}$ & $2,22 \mathrm{a}$ & $3,21 \mathrm{a}$ & $3,98 \mathrm{a}$ & $3,21 \mathrm{a}$ & $0,067 \mathrm{a}$ & $0,165 \mathrm{a}$ \\
\hline & $\mathrm{S}$ & 0,11 & 0,27 & 0,43 & 0,39 & 1,05 & 1,06 & 0,022 & 0,014 \\
\hline \multirow{2}{*}{ M } & $\mathrm{D}_{\text {collar }}$ & $0,85 b$ & $1,54 \mathrm{~b}$ & $2,41 b$ & $3,83 b$ & $4,97 \mathrm{~b}$ & $4,17 \mathrm{~b}$ & $0,087 \mathrm{~b}$ & $0,174 \mathrm{~b}$ \\
\hline & $\mathrm{S}$ & 0,13 & 0,40 & 0,45 & 0,50 & 1,52 & 1,54 & 0,032 & 0,015 \\
\hline
\end{tabular}

Table 9. Height of plants non-inoculated and inoculated (M) at the time of transfer to the nursery (50 days) and 1, 2 and 3 years after transfer to the nursery. The increases of height in that period $(\Delta \mathrm{h})$, the monthly increases in height $(\Delta \mathrm{h} / \Delta \mathrm{t})$ and relative growth rate (RGR) are also shown. Values of standard deviation (S) and the mean values of different treatments followed by different letters that correspond to parameters with statistically significant differences for $\mathrm{p}<0.05$ are represented.

\begin{tabular}{|c|c|c|c|c|c|c|c|c|c|}
\hline \multirow[b]{2}{*}{$\mathrm{h}$} & & \multicolumn{5}{|c|}{ Height $(\mathrm{cm})$} & \multirow{2}{*}{$\begin{array}{l}\Delta \mathrm{h} \\
(\mathrm{cm})\end{array}$} & \multirow{2}{*}{$\begin{array}{c}\Delta \mathrm{h} / \Delta \mathrm{t} \\
(\mathrm{cm} / \mathrm{month})\end{array}$} & \multirow{2}{*}{$\begin{array}{c}\text { TCR } \\
(\mathrm{mm} / \mathrm{cm} / \mathrm{month})\end{array}$} \\
\hline & & 50 days & $\begin{array}{r}150 \\
\text { days }\end{array}$ & $\begin{array}{c}\text { Year } \\
1\end{array}$ & $\begin{array}{c}\text { Year } \\
2\end{array}$ & $\begin{array}{c}\text { Year } \\
3\end{array}$ & & & \\
\hline \multirow{2}{*}{ NM } & $\mathrm{h}$ & $17,3 \mathrm{a}$ & $28,0 \mathrm{a}$ & $52,3 b$ & $83,4 a$ & $108,0 \mathrm{a}$ & $90,8 \mathrm{a}$ & $2,16 a$ & $0,191 \mathrm{a}$ \\
\hline & $\mathrm{S}$ & 2,9 & 5,0 & 12,8 & 29,5 & 45,7 & 43,1 & 1,03 & 0,025 \\
\hline \multirow[t]{2}{*}{ M } & $\mathrm{h}$ & $17,5 \mathrm{a}$ & $31,0 \mathrm{~b}$ & $61,0 \mathrm{c}$ & $100,3 b$ & $125,6 \mathrm{~b}$ & $108,1 b$ & $2,57 \mathrm{~b}$ & $0,200 \mathrm{~b}$ \\
\hline & $\mathrm{S}$ & 3,7 & 5,6 & 12,4 & 33,8 & 50,5 & 47,0 & 1,12 & 0,017 \\
\hline
\end{tabular}


Table 10. Diameter at the collar level of plants non inoculated (NM) and inoculated (M) at the time of transfer to the nursery (50 days) and 1,2 and 3 years after transfer to the nursery. The increases in diameter during this period $(\Delta \mathrm{D})$, the monthly increases in diameter $(\Delta \mathrm{D} / \Delta \mathrm{t})$ and relative growth rate (RGR) are also shown. Values of standard deviation (S) and the mean values of different treatments followed by different letters that correspond to parameters with statistically significant differences for $p<0.05$ are represented.

\begin{tabular}{|c|c|c|c|c|c|c|c|c|c|}
\hline \multirow[b]{2}{*}{$\mathrm{D}_{\text {collar }}$} & & \multicolumn{5}{|c|}{ Stem diameter at the collar level $(\mathrm{cm})$} & \multirow[b]{2}{*}{$\begin{array}{l}\Delta \mathrm{D} \\
(\mathrm{cm})\end{array}$} & \multirow[b]{2}{*}{$\begin{array}{c}\Delta \mathrm{D} / \Delta \mathrm{t} \\
(\mathrm{cm} / \mathrm{month})\end{array}$} & \multirow{2}{*}{$\begin{array}{c}\text { TCR } \\
(\mathrm{mm} / \mathrm{cm} / \mathrm{month})\end{array}$} \\
\hline & & $\begin{array}{c}50 \\
\text { days }\end{array}$ & $\begin{array}{l}150 \\
\text { days }\end{array}$ & $\begin{array}{c}\text { Year } \\
1\end{array}$ & $\begin{array}{c}\text { Year } \\
2\end{array}$ & $\begin{array}{c}\text { Year } \\
3\end{array}$ & & & \\
\hline \multirow{2}{*}{ NM } & $\mathrm{D}_{\text {collar }}$ & $0,38 \mathrm{a}$ & $0,57 \mathrm{a}$ & $1,15 \mathrm{a}$ & $1,81 \mathrm{a}$ & $2,56 \mathrm{a}$ & $2,28 \mathrm{a}$ & $0,054 \mathrm{a}$ & $0,196 \mathrm{a}$ \\
\hline & $\mathrm{S}$ & 0,08 & 0,17 & 0,46 & 0,94 & 1,00 & 0,93 & 0,022 & 0,026 \\
\hline \multirow{2}{*}{ M } & $D_{\text {collar }}$ & $0,41 \mathrm{a}$ & $0,62 \mathrm{a}$ & $1,41 b$ & $2,32 b$ & $3,38 b$ & $2,93 b$ & $0,070 \mathrm{~b}$ & $0,206 b$ \\
\hline & $\mathrm{S}$ & 0,11 & 0,21 & 0,58 & 1,16 & 1,52 & 1,41 & 0,034 & 0,008 \\
\hline
\end{tabular}

Table 11. Growth in height of $\mathrm{M}$ and $\mathrm{NM}$ plants after transfer to acclimatization conditions in the nursery from 180 days to 2 years. Values of standard deviation (S) and the mean values of different treatments followed by different letters that correspond to parameters with statistically significant differences for $p<0.05$ are represented.

\begin{tabular}{rlllllll}
\hline \multirow{2}{*}{$\mathrm{h}$} & \multicolumn{4}{c}{ Height $(\mathrm{cm})$} & \multirow{2}{*}{$\mathrm{h}$} & $\begin{array}{c}\Delta \mathrm{h} / \Delta \mathrm{t} \\
(\mathrm{cm} / \mathrm{month})\end{array}$ & $\begin{array}{c}\mathrm{TCR} \\
(\mathrm{mm} / \mathrm{cm} / \mathrm{month})\end{array}$ \\
\cline { 3 - 5 } & & 180 days & Year 1 & Year 2 & $(\mathrm{cm})$ & $(\mathrm{cm} / \mathrm{m}$ & \\
\multirow{2}{*}{$\mathrm{NM}$} & $\mathrm{h}$ & $38,4 \mathrm{a}$ & $48,9 \mathrm{a}$ & $96,8 \mathrm{a}$ & $58,4 \mathrm{a}$ & $2,43 \mathrm{a}$ & $0,247 \mathrm{a}$ \\
& $\mathrm{S}$ & 12,3 & 16,9 & 37,8 & 27,9 & 1,16 & 0,029 \\
\hline \multirow{2}{*}{$\mathrm{M}$} & $\mathrm{h}$ & $38,6 \mathrm{a}$ & $54,4 \mathrm{~b}$ & $103,0 \mathrm{a}$ & $64,4 \mathrm{~b}$ & $2,68 \mathrm{~b}$ & $0,263 \mathrm{~b}$ \\
& $\mathrm{~S}$ & 12,0 & 15,6 & 23,4 & 13,1 & 0,55 & 0,022 \\
\hline
\end{tabular}

Table 12. Growth in diameter at the collar level of the stem of M and NM plants after transfer to conditions of acclimatization in the nursery from 180 days to 2 years. Values of standard deviation (S) and the mean values of different treatments followed by different letters that correspond to parameters with statistically significant differences for $\mathrm{p}<0.05$ are represented.

\begin{tabular}{llllllll}
\hline \multirow{2}{*}{$\mathrm{D}_{\text {collar }}$} & \multicolumn{5}{c}{$\begin{array}{c}\text { Stem diameter at the collar level } \\
(\mathrm{cm})\end{array}$} & \multicolumn{5}{c}{$\begin{array}{c}\Delta \mathrm{D} \\
(\mathrm{cm})\end{array}$} & $\begin{array}{c}\Delta \mathrm{D} / \Delta \mathrm{t} \\
(\mathrm{cm} / \mathrm{mon} \text { th })\end{array}$ & $\begin{array}{c}\text { TCR } \\
(\mathrm{mm} / \mathrm{cm} / \mathrm{month})\end{array}$ \\
\cline { 2 - 5 } & \multicolumn{1}{c}{ 180 days } & Year 1 & Year 2 & & & \\
\multirow{2}{*}{$\mathrm{NM}$} & $\mathrm{D}_{\text {collar }}$ & $0,76 \mathrm{a}$ & $1,25 \mathrm{a}$ & $2,32 \mathrm{a}$ & $1,56 \mathrm{a}$ & $0,065 \mathrm{a}$ & $0,257 \mathrm{a}$ \\
& $\mathrm{S}$ & 0,64 & 1,14 & 1,05 & 1,00 & 0,112 & 0,052 \\
\hline \multirow{2}{*}{$\mathrm{M}$} & $\mathrm{D}_{\text {collar }}$ & $0,84 \mathrm{~b}$ & $1,48 \mathrm{~b}$ & $2,69 \mathrm{~b}$ & $1,85 \mathrm{~b}$ & $0,077 \mathrm{~b}$ & $0,276 \mathrm{~b}$ \\
& $\mathrm{~S}$ & 0,18 & 0,69 & 1,12 & 0,94 & 0,039 & 0,043 \\
\hline
\end{tabular}

